\title{
The Development of Magnesium-Based Resorbable and Iron-Based Biocorrodible Metal Scaffold Technology and Biomedical Applications in Coronary Artery Disease Patients
}

\author{
Alexandre Hideo-Kajita ${ }^{1,+}+\mathbb{D}$, Samuel Wopperer ${ }^{2,+}$, Vinícius Bocchino Seleme ${ }^{3}$, \\ Marcelo Harada Ribeiro ${ }^{3}$ and Carlos M. Campos ${ }^{3,4, *}$ \\ 1 Division of Interventional Cardiology, MedStar Cardiovascular Research Network, \\ MedStar Washington Hospital Center, Washington, DC 20010, USA \\ 2 School of Medicine, Georgetown University, Washington, DC 20057, USA \\ 3 Heart Institute (InCor), University of São Paulo Medical School, São Paul SP 05403-900, Brazil \\ 4 Hospital Israelita Albert Einstein, São Paulo SP 05652-900, Brasil \\ * Correspondence: carlosacampos1@gmail.com; Tel.: +55-(11)-2661-5000; Fax: +55-(11)-3082-2354 \\ + These authors contributed equally to this manuscript.
}

Received: 12 July 2019; Accepted: 9 August 2019; Published: 28 August 2019

\begin{abstract}
In the treatment of atherosclerotic disease patients, the adoption of second-generation drug-eluting stents (DES) in percutaneous coronary intervention reduced the occurrence of in-stent restenosis (ISR) and acute stent thrombosis (ST) when compared to bare metal stents and 1st generation DES. However, the permanent encaging of the vessel wall by any of the metallic stents perpetuates the inflammation process and prevents vasomotion in the treated segment. Aiming to overcome this issue, the bioresorbable scaffold (BRS) concept was developed by providing transient vascular radial support to the target segment during the necessary time to heal and disappearing after a period of time. Close to 20 years since BRS technology was first reported, the interventional cardiology field saw the rise and fall of several BRS devices. Although iron-based BRS is an emerging technology, currently, magnesium-alloy resorbable scaffolds devices are supported with the most robust data. This manuscript aims to review the concept of magnesium-based BRS devices, as well as their bioresorption mechanisms and the status of this technology, and the clinical outcomes of patients treated with magnesium BRS and to review the available evidence on iron-based BRS technology.
\end{abstract}

Keywords: coronary artery disease; bioresorbable scaffold; magnesium; resorbable metal scaffold

\section{Introduction}

In the treatment of atherosclerotic disease patients, the adoption of second-generation drug-eluting stents (DES) in percutaneous coronary intervention reduced the occurrence of in-stent restenosis (ISR) and acute stent thrombosis (ST) when compared to bare metal stents and 1st generation DES [1-5].

The historical limitations of the DES technology, particularly due to the perpetuation of the inflammation process by the permanent encaging of the vessel wall, led to the development of the Bioresorbable Scaffolds (BRS) concept, namely providing vascular radial support (i.e., scaffolding) to the treated segment during the necessary time to heal the vessel wall and disappearing after a period of time [6]. However, close to 20 years since Tamai et al. first reported the BRS technology concept, the field of interventional cardiology saw the rise and fall of several BRS devices [7]. Although iron-based scaffolds are an emerging technology, currently, magnesium-alloy resorbable scaffold devices are supported with the most robust data [8-10]. This manuscript aims to review the magnesium-based BRS 
devices concept, bioresorption mechanisms and status of this technology, and the clinical outcomes of patients treated with magnesium BRS (1) and to review the available evidence on iron-based BRS technology (2).

\section{Transient Scaffolding of the Vessel Wall}

Bioresorbable Scaffolds (BRS) technology, both polymeric and metallic, intended to overcome the present unfavorable outcomes regarding the permanent encaging of vessel wall by DES [2,11]. BRS technology promotes transient vascular support to the vessel wall, acutely avoiding luminal narrowing caused by intima or media dissection, intraparietal hematoma, or acute elastic recoil [6]. Afterwards, it circumvents the development of in-segment (device plus edges) neointimal hyperplasia or scaffold thrombosis by disappearing from the vessel wall after a period of time due to the bioresorption process [12-14]. In addition, transient scaffolding of BRS favors vasomotion restoration, adaptive shear stress conditions, late luminal enlargement, and expansive remodeling in the previously treated segment and as a consequence, reduces bleeding complications by shortening the required DAPT time [14]. Finally, after complete resorption of the device, the platform imprint will not prevent a reintervention in the segment, neither for PCI nor coronary artery bypass graft (CABG) if needed.

\section{Magnesium-Based Devices}

\subsection{Biological Effects of Magnesium}

Magnesium, an alkaline earth divalent cation $\left(\mathrm{Mg}^{2+}\right)$, is predominantly an intracellular cation, the 2 nd most common after potassium and the 4 th in the extracellular matrix. Around $60-65 \%$ of which was presented as ionized or free $[15,16]$. The concentration of $\mathrm{Mg}^{2+}$ in human physiology is determined by intestinal absorption ( $1 / 3$ of the overall daily western dietary income), bone exchange (i.e., largest body reservoir), and renal depuration taking between 25 to 81 hours $[17,18]$.

Ionic magnesium is essential for some enzymatic reactions, protein synthesis, metabolism, and ion channel regulation. In the later, it inhibits the calcium-induced release channels and stabilizes the cellular membrane by increasing the excitability threshold, preventing eclampsia, arrhythmias, and seizures for example [17-19]. Also, the divalent cation characteristics of $\mathrm{Mg}^{2+}$ shifts the membrane's ionic charge distribution making it prone to negative electromagnetic properties, consequently, lowering in-vivo thrombogenicity compared to the positively charged ones [20-22]. The thrombogenic protective effect of $\mathrm{Mg}^{2+}$ was observed in a series of porcine shunt model studies where magnesium-based BRS had less thrombus formations attached to the struts than durable metallic alloys DES [23-25]. Finally, pre-clinical studies also suggest that ionic magnesium may present protective effect against vasoconstriction induced by endothelin-1 $[26,27]$.

\subsection{Magnesium Alloy Biocompatibility and Resorption}

A metal stent biocompatibility study reported a significant dielectric spectroscopy interaction between the metallic stents and cell membrane of erythrocytes, albeit this phenomenon was not related to unfavorable clinical outcomes [28]. For this, magnesium alloy devices were developed aiming to increase the biocompatibility between device versus blood and vessel wall. Magnesium has a high biocompatibility but low tensile force and accelerated corrosion rate (ACR) with an increased hydrogen $\left(\mathrm{H}_{2}\right)$ evolution rate $[9,20]$, which are $\mathrm{H}_{2}$ pockets formations next to metal surface and the alkalization $\left(\mathrm{OH}^{-}\right)$of the surrounding solution mostly due to the ACR. Biologically, ACR delays the intimal healing process inducing local necrosis and separating the tissue layers $[9,29,30]$. The ACR issue solution came from magnesium alloys extensively used in aerospace since the addition of low levels of rare-earth metal elements decelerates the ACR process, thus minimizing the $\mathrm{H}_{2}$ evolution rate issue. After many attempts, two alloys remained as valuable options for BRS application, the AE21 (SHL-Alubin Ltd., Kiryat Biolik, Israel) and WE43 (Magnesium Elektron Ltd., Swinton, Manchester, UK) [29]. Magnesium AE21 alloy is a composite of $97.0 \%$ of $\mathrm{Mg}, 2.0 \%$ of Aluminum (Al), and 1.0\% of rare-earth metals 
[Cerium (Ce), Praseodymium (Pr), and Neodymium (Nd)] [8], and the WE43 alloy has $93.6 \%$ of $\mathrm{Mg}$, $3.7-4.3 \%$ of Yttrium $(\mathrm{Y}), 2.4-4.4 \%$ of rare-earth metals (predominantly Neodymium, $\mathrm{Nd}$ ), and $0.4 \%$ of Zirconium ( $\mathrm{Zr}$ ) [9,30]. From the biologic point of view, these alloys considerably improved the predictability of the degradation process providing longer platform integrity [29] and optimizing the radial strength-to-weight ratio of metallic Magnesium BRS platforms, which are now comparable to aluminum and steel alloys with a lighter platform [29-31].

The complete resorption time of magnesium-based platforms vary depending on magnesium alloy, platform characteristics (strut thickness and width), and the presence or not of polymeric coating. In porcine models implanted with AE21 alloy, uncoated platform device struts were observed at 56 days and an expected complete resorption time $\leq 89.4$ days [8]. In fact, an objective resorption observation data came from a WE43 alloy uncoated platform Lekton Magic (Biotronik AG, Bülach, Switzerland) presenting a complete in-vivo resorption in $<2$ months $[9,32,33]$. The addition of polymeric coating in the platform like Magmaris (DREAMS 2G-Biotronik AG, Bülach, Switzerland) significantly delayed the in-vivo resorption time up to 12 months when $95 \%$ of platform struts were fully resorbed as a consequence providing effective 3 months of scaffolding vessel support time [34].

The magnesium alloy resorption main chemical process is hydrolysis, where $\mathrm{Mg}^{2+}$ and two $\mathrm{H}_{2} \mathrm{O}$ molecules are converted to magnesium hydroxide $\left[\mathrm{Mg}^{2+}\left(\mathrm{OH}^{-}\right)_{2}\right]$ and hydrogen gas $\left(\mathrm{H}_{2}\right)$ followed by a progressive replacement of magnesium by calcium $\left(\mathrm{Ca}^{2+}\right)$ and phosphate $\left(\mathrm{PO}_{4}{ }^{3-}\right)$ into a soft amorphous hydroxyapatite imprint $\left[\mathrm{Ca}_{5}{ }^{2+}\left(\mathrm{PO}_{4}{ }^{3-}\right)_{3} \mathrm{OH}^{-}\right]$. Based on the in vitro and in-vivo observations, these processes occur simultaneously but in a multi-phased fashion. First, the initial corrosion phase starts with the hydrolytic process being homogeneously distributed over platform surface. In the second phase, the resorption process is now heterogeneous, deeply advancing to the inner parts of the struts through microfractures in the surface of the platform. Finally, in the third and last phase, the calcium and phosphate are now homogenously distributed over the imprint remains of the platform until the complete substitution of the residual Magnesium for soft amorphous hydroxyapatite (Figure 1) [21,32].

\subsection{First Experience of a Magnesium Alloy Device}

In 2003, Heublein B et al. was the first group to report the concept of a magnesium-based AE21 alloy scaffold (non-commercial). Their uncoated scaffold platforms (mass of $4 \mathrm{mg}$ ) were prototyped on extruded $2.0 \mathrm{~mm}$ diameter AE21 alloy laser cut tubes with a strut thickness of 150-200 $\mu \mathrm{m}$ (uneven thickness) and $10 \mathrm{~mm}$ length [8]. The characteristics of each device is presented in Table 1.

In a pre-clinical swine model study, 11 subjects were included with 9 stents in the left anterior descending artery (LAD), 9 in the left circumflex artery (LCx), and 2 in the right coronary artery (RCA) totalling 20 stents with one implanted per vessel. All treated segments ranged from 2.5 to $3.5 \mathrm{~mm}$ in proximal reference vessel diameter (RVD) [8]. Each animal was assessed by angiography followed by necropsy which were performed in 3 pigs ( 5 devices) at 10 days, 4 pigs ( 7 devices) at 35 days, and 3 pigs ( 6 devices) at 56 days. Intravascular ultrasound (IVUS) was performed in the 35- and 56-day group of animals. Overall, the imaging and pathology assessments showed patent treated segments and non-thrombosed devices and non-infarcted myocardium except for 1 of the animals (with 2 devices), which died due to scaffold thrombosis $<10$ days. Moreover, IVUS assessment did not show any significant intimal thickening up to 56 days after the device implantation [8]. 


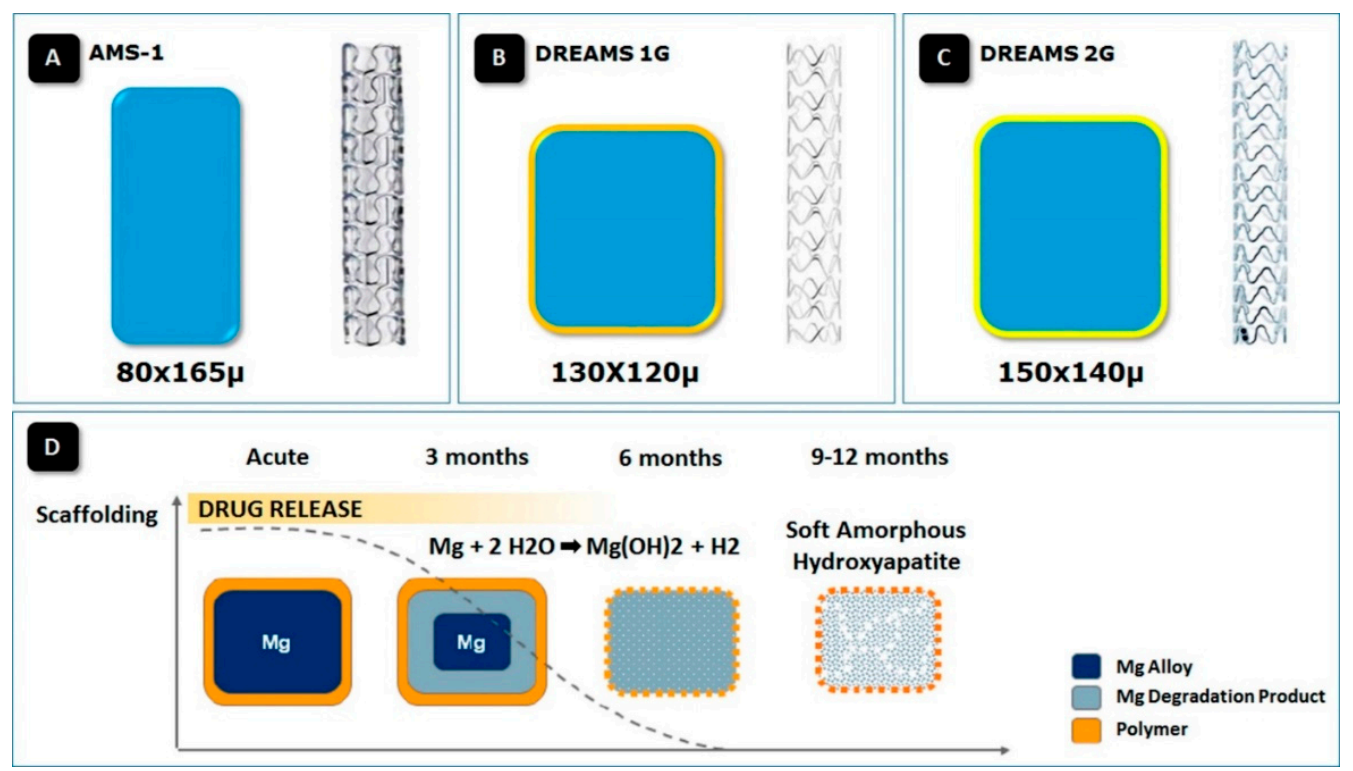

Figure 1. (A) Schematic cross-sectional profile of magnesium scaffolds struts of (A) uncoated, non-eluting, AMS-1 with $80 \times 165 \mu$; (B) DREAMS 1st Generation (DREAMS 1G) with $130 \times 120 \mu$ struts and (C) DREAMS 2nd generation (2G) with $150 \times 140 \mu$ struts. The poly(lactide-co-glycolide)-coating with paclitaxel elution of the DREAMS $1 \mathrm{G}$ scaffold is indicated by the thin light orange layer. The PLA coating with sirolimus elution of the DREAMS 2G scaffold is indicated by the thin dark orange layer; and (D) Schematic representation of the resorption process in the drug-eluting absorbable magnesium scaffold. The release of the anti-proliferative drug occurs within the first 3 months after device implantation. Hydrolysis of the scaffold affects the radial strength of the scaffold, resulting in a gradual resorption of the device into a soft amorphous hydroxyapatite at 9 months follow-up. AMS-1, first-generation bare absorbable metal scaffold; DREAMS, Drug-Eluting Absorbable Metal Scaffold, (Reproduced from: Campos CM et al. Int. J. Mol. Sci. 2013, 14(12), 24492-24500.) [35].

\subsection{Lekton Magic Coronary Stent}

Lekton Magic Coronary Stent (Biotronik AG, Bülach, Switzerland) was a single tube WE43 alloy laser sculpted platform with 4 crowns and 4 unbowed cross-links in the longitudinal scaffold axis mounted over a dedicated balloon and no radiopaque markers. The device showed a $5 \%$ elastic recoil, collapse pressure of $0.8 \mathrm{~atm}$, and strut thickness/width of $165 / 80 \mu \mathrm{m}$ (Table 1) [9].

In the pre-clinical porcine study $(n=33)$, the animals implanted with Lekton Magic showed a higher post-procedure minimum lumen diameter (MLD) of $1.49 \mathrm{~mm}$ than the BMS group $(1.34 \mathrm{~mm})$ and a luminal increase from 1.49 to $1.69 \mathrm{~mm}(p<0.001)$ at 12 weeks [9].

The Lekton Magic Stent was studied in critically ischemic peripheral artery disease (PAD) patients $(n=20)$ and 23 lesions were included in this exploratory study. After 1-month follow-up, normal flow assessed by doppler was observed in 18 patients and arterial occlusions in 2 subjects leading to surgical revascularization in one of the cases [9].

\subsection{Absorbable Metal Stent First Generation (AMS-1)}

The Absorbable Metal Scaffold from the first generation (AMS-1) was a single tube laser sculpted WE43 alloy platform with 4 crowns and 4 inter-crown links, and no radiopaque markers. The device's crossing profile was $1.4 \mathrm{~mm}, 0.8 \mathrm{~atm}$ of collapse pressure, $6-7 \%$ of elastic recoil and longitudinal shortening of $<5 \%[33,35]$. AMS- 1 was a pre-mounted semi-compliant balloon crimped device with strut thickness/width of $165 / 80 \mu \mathrm{m}$, and the available device sizes were 3.0 and $3.5 \mathrm{~mm}$ in diameter and 10 or $15 \mathrm{~mm}$ in length (Table 1) [36].

AMS-1 safety and feasibility were studied in the PROGRESS-AMS trial. A single arm, prospective, multicenter study enrolled 63 patients with stable coronary artery disease (CAD). In the quantitative 
angiographic assessment at 4 months, the in-scaffold late lumen loss (LLL) was $1.08 \pm 0.49 \mathrm{~mm}$ with a proximal margin luminal reduction from $2.60 \pm 0.47 \mathrm{~mm}$ to $2.23 \pm 0.65 \mathrm{~mm}(p<0.001)$. In the IVUS assessment, the overall decrease of external elastic membrane-volume (EEM) of $42 \%$ with neointimal formation of $45 \%$ and $18 \%$ of in-scaffold area decrease. At 12 months, there was $27 \%$ of ischemic-driven target lesion revascularization with no death, myocardial infarction (MI), or scaffold thrombosis (ST) events [36].

\subsection{DRug-Eluting Absorbable Metal Scaffold (DREAMS)}

DREAMS (AMS-3.0 - Biotronik AG, Bülach, Switzerland) was a paclitaxel-eluting poly-lactide-co-glycolide (PLGA) coated AMS, a redesigned coated version of AMS-1 [10,37]. Similarly, this platform was also a WE43 alloy with 6 crowns and 3 links, strut thickness/width of 120/130 $\mu \mathrm{m}$, a PLGA coating with thickness of 1 to $3 \mu \mathrm{m}$, paclitaxel drug density of $0.07 \mu \mathrm{g} / \mathrm{mm}^{2}$, and a higher collapse pressure of $1.5 \mathrm{~atm}$ compared to AMS-1 (0.8 atm) [37]. DREAMS available sizes were $3.25 \mathrm{~mm}$ to $3.5 \mathrm{~mm}$ in diameter and $16 \mathrm{~mm}$ in length (Table 1) [10].

In the DREAMS feasibility pre-clinical study including 50 mini-pigs totaling 109 coronaries, AMS-3.0 stents were implanted in 73 vessels, and 36 vessels were implanted with paclitaxel DES (TAXUS and EucaTAX). At 6 months, Angiographic LLL, histological intimal area, fibrin score, and endothelialization results of DREAMS was equivalent to TAXUS liberté (TAXUS ${ }^{\circledR}$ Liberté $^{\circledR}$; Boston Scientific, Natick, MA, USA) and was superior to EucaTAX (eucatech AG, Rheinfelden, Germany) [37].

BIOSOLVE-I (NCT01168830) [10] was a First-In-Man, single-arm, prospective, multi-center study. In total, 46 patients (47 lesions) were included in the analysis. In-scaffold LLL was not significantly changed between 6 and 12 months, $0.65 \pm 0.50 \mathrm{~mm}$ and $0.52 \pm 0.39 \mathrm{~mm}$, respectively $(p=0.254)$, lower than previous generation AMS-1 $(1.08 \pm 0.49 \mathrm{~mm})$. In-scaffold MLD was reduced significantly at 12 months $(2.56 \pm 0.35 \mathrm{~mm}$ versus $2.06 \pm 0.47 \mathrm{~mm}, p<0.001)$. Serial OCT data at 12 months was available in 7 patients $(15 \%)$, and $99.8 \%(5779 / 5791)$ of the assessed struts were apposed in 3 patients. The remaining $0.2 \%$ of the struts were malapposed (persistent or late acquired). Target lesion failure (TLF) at 12 months occurred in 3 patients $(7 \%)$ but did not cause cardiac death or scaffold thrombosis [10].

\subsection{Sirolimus DRug-Eluting Absorbable Metal Scaffold (DREAMS 2nd Generation-2G)}

Magmaris (DREAMS 2G-Biotronik AG, Bülach, Switzerland) was a balloon expanded sirolimus-eluting poly-L-lactide acid (PLLA) coated resorbable magnesium scaffold (RMS) with 6 crowns and 2 links mounted over a rapid-exchange monorail semi-compliant balloon. In this platform, the strut thickness/width was $150 / 150 \mu \mathrm{m} ; 3.0$ and $3.5 \mathrm{~mm}$ in diameter; and 15, 20, or $25 \mathrm{~mm}$ in length. Also, the anti-proliferative eluting-drug and polymeric coating were substituted for sirolimus (drug density of $1.4 \mu \mathrm{g} / \mathrm{mm}^{2}$ ) and PLLA $(7 \mu \mathrm{m})$. In this second-generation platform, 2 non-resorbable tantalum radiopaque markers were added in the proximal and distal crowns (Table 1) [38].

In First-In-Man Biosolve-II (NCT01960504),123 patients (123 lesions) were included in this single-arm, prospective, multi-center study [38]. At 6 and 12 months, the in-segment LLL was $0.37 \pm 0.25 \mathrm{~mm}$ and $0.39 \pm 0.27 \mathrm{~mm}$, respectively [38,39]. Post-procedure mean scaffold area by IVUS was $6.24 \pm 1.15 \mathrm{~mm}^{2}$ and $6.21 \pm 1.22 \mathrm{~mm}^{2}$ at 6 months with neointimal area of $0.08 \pm 0.09 \mathrm{~mm}^{2}$ [38]. There was no significant change in minimum lumen area (MLA) of 4.80 and $4.69 \mathrm{~mm}^{2}$ between 6 and 12 months, respectively ( $p=0.700$ ) [39]. In-scaffold EEM, plaque area did not vary over 12 months follow-up [13]. OCT assessment at baseline, 6 , and 12 months showed a significant decrease of MLA from $6.32 \mathrm{~mm}^{2}$ to $4.53 \mathrm{~mm}^{2}$ and $4.81 \mathrm{~mm}^{2}(p=0.032)$, respectively and no intraluminal masses were observed (Figure 2) $[13,38,39]$. In the proximal and distal edge vascular response (EVR) assessment, there was no meaningful changes in grayscale IVUS, virtual histology IVUS, and OCT except for a Fibrous plaque area reduction of $0.5 \mathrm{~mm}^{2}(p=0.017)$ in the proximal segment of the device at 12 months (Figure 3) [14]. 


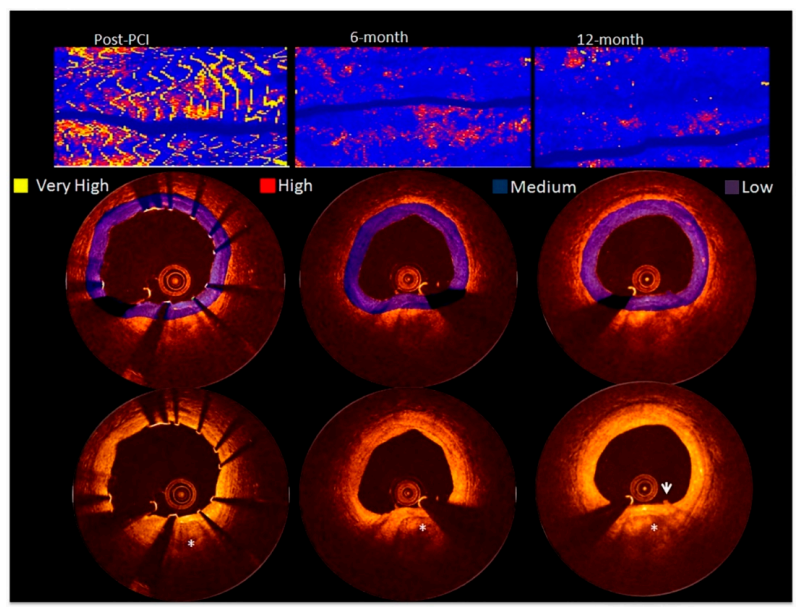

Figure 2. Optical coherence tomography of DREAMS 2G. At the top, 3 spread out panels showing the attenuation maximum values. Post-PCI, the attenuation values that correspond to the scaffold struts are very high (yellow). The scaffold design can be recognized. Those very high values subsided over time, corresponding to the bioresorption process of the struts. In the middle row, 3 OCT frames are depicted. Post-PCI, the struts are shown with very high attenuation values, which disappeared over time. At the bottom, post-PCI struts are bright structures with shadowing behind. In the corresponding frames at 6 and 12 months (please note the calcium marked by *), a remnant of struts is present at $5 \mathrm{o}^{\prime}$ clock (arrow), (Reproduced from: Garcia-Garcia HM et al. Int. J. Cardiol. 2018 Mar 15, 255, 22-28.) [13].
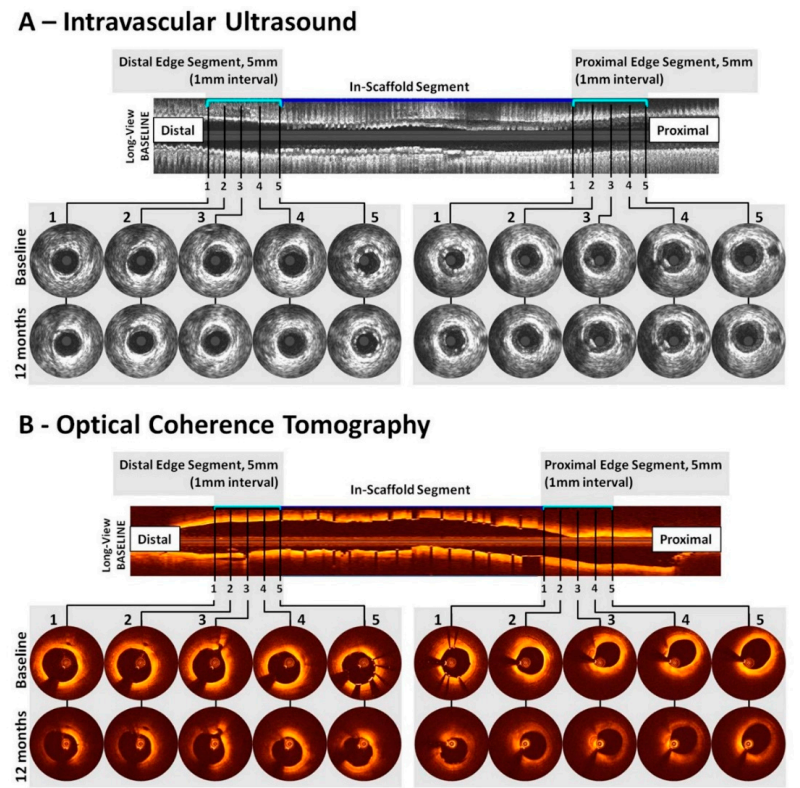

Figure 3. Magmaris edge vascular response segment and frame level analysis panel. Intravascular Ultrasound (A); and Optical Coherence Tomography (B), (Reproduced from: Hideo-Kajita A et al. Cardiovasc Revasc Med. 2019 May, 20(5), 392-398.) [14].

Magmaris vasomotion testing at 6 and 12 months in Biosolve-II trial was positive in 80\% (20/25) and $79 \%(11 / 14)$ of the patients [38]. TLF rate at 6 and 24 months was $3 \%(4 / 123)$ and $6 \%(7 / 116)$ of the patients [38,40], and of these 7 events, 2 were cardiac deaths, $1 \mathrm{MI}$, and 4 clinically-driven target lesion revascularizations (TLR) [40]. There were no definite or probable ST cases at 24 months [38-40].

A patient-level pooled multivariate analysis assessing the TLF rate of Magmaris (Biosolve-II and -III trials) versus Orsiro (Bioflow II trial) showed no significant difference in the unadjusted nor in the adjusted data [41,42]. Still, there is no randomized study comparing Magmaris and a 2nd Generation Metallic DES. 
Table 1. Magnesium-based bioresorbable scaffolds characteristics.

\begin{tabular}{|c|c|c|c|c|c|c|c|c|c|c|c|c|c|c|c|c|c|}
\hline \multirow{2}{*}{ Device } & \multirow{2}{*}{ Mg Alloy } & \multirow{2}{*}{$\begin{array}{l}\text { Scaffolding } \\
\text { Time }\end{array}$} & \multirow{2}{*}{$\begin{array}{l}\text { Resorption } \\
\text { Time, Months }\end{array}$} & \multirow{2}{*}{$\begin{array}{c}\text { Coating } \\
\text { (Thickness) }\end{array}$} & \multirow{2}{*}{$\begin{array}{l}\text { Eluting-Drug } \\
\text { (Drug Density) }\end{array}$} & \multirow{2}{*}{$\begin{array}{l}\text { Radiopaque } \\
\text { Marker }\end{array}$} & \multicolumn{2}{|c|}{ Platform } & \multicolumn{2}{|c|}{ Struts, $\mu \mathrm{m}$} & \multicolumn{2}{|c|}{ Device Sizes, mm } & \multirow{2}{*}{$\begin{array}{c}\text { Elastic } \\
\text { Recoil, \% }\end{array}$} & \multirow{2}{*}{$\begin{array}{l}\text { Collapse } \\
\text { Pressure, } \\
\text { Atm }\end{array}$} & \multirow{2}{*}{$\begin{array}{c}\text { Crossing } \\
\text { Profile, } \\
\text { mm }\end{array}$} & \multirow{2}{*}{$\begin{array}{c}\text { Longitudinal } \\
\text { Shortening, } \\
\%\end{array}$} & \multirow{2}{*}{ Ref. } \\
\hline & & & & & & & Crowns & Links & Thickness & Width & Diameter & Length & & & & & \\
\hline $\begin{array}{l}\text { Heublein et al. } \\
\text { prototype }\end{array}$ & AE21 & NA & NA & No & No & No & NA & NA & $\begin{array}{c}150-200 \\
*\end{array}$ & NA & 2.0 & 10 & NA & $\mathrm{NA}$ & NA & NA & {$[8]$} \\
\hline $\begin{array}{l}\text { Lekton Magic } \\
\text { Coronary Stent }\end{array}$ & WE43 & $\mathrm{NA}$ & $<2$ & No & No & No & 4 & 4 & 165 & 80 & NA & NA & $5 \%$ & 0.8 & 1.2 & NA & [9] \\
\hline AMS-1 & WE43 & $\mathrm{NA}$ & $\sim 1$ & No & No & No & 4 & 4 & 165 & 80 & $\begin{array}{l}3.0 \\
3.5\end{array}$ & $\begin{array}{l}10 \\
15\end{array}$ & 6 to $7 \%$ & 0.8 & 1.4 & $<5 \%$ & {$[33,37]$} \\
\hline $\begin{array}{l}\text { AMS-3.0 } \\
\text { (DREAMS) }\end{array}$ & WE43 & NA & $\sim 3$ & $\begin{array}{c}\text { PLGA (1-3 } \\
\mu \mathrm{m})\end{array}$ & $\begin{array}{c}\text { Paclitaxel } \\
\left(0.07 \mu \mathrm{\mu g} / \mathrm{mm}^{2}\right)\end{array}$ & No & 6 & 3 & 120 & 130 & $\begin{array}{l}3.25 \\
3.5\end{array}$ & 16 & $9 \%$ & 1.5 & 1.2 & NA & {$[10,37]$} \\
\hline $\begin{array}{l}\text { Magmaris } \\
\text { (DREAMS 2G) }\end{array}$ & WE43 & $\begin{array}{l}\text { up to } 3 \\
\text { months }\end{array}$ & $\sim 12$ & $\operatorname{PLLA}(7 \mu \mathrm{m})$ & $\begin{array}{c}\text { Sirolimus } \\
\left(1.4 \mu \mathrm{g} / \mathrm{mm}^{2}\right)\end{array}$ & $2 \times$ tantalum & 6 & 2 & 150 & 150 & $\begin{array}{l}3.0 \\
3.5\end{array}$ & $\begin{array}{l}15 \\
20 \\
25\end{array}$ & $<8 \%$ & 0.8 & 1.75 & NA & [38] \\
\hline DREAMS 3G & WE43 & $\geq 3$ months & $\sim 12$ & PLLA (NA) & $\begin{array}{l}\text { Sirolimus } \\
\left(1.4 \mu \mathrm{g} / \mathrm{mm}^{2}\right)\end{array}$ & $\begin{array}{l}\text { Yes (New } \\
\text { Concept) }\end{array}$ & NA & NA & $\begin{array}{l}99 \\
117 \\
147\end{array}$ & 150 & $\begin{array}{l}2.5 \\
3.0 \\
3.5 \\
4.0\end{array}$ & $\begin{array}{l}13 \\
18 \\
22 \\
30\end{array}$ & $\mathrm{NA}$ & NA & NA & NA & [43] \\
\hline
\end{tabular}

* Uneven thickness; Abbreviations: AMS-1 = Absorbable Metal Stent First Generation; Mg = Magnesium; NA = non-available; PLGA = poly lactide-co-glycolide; PLLA = poly L-Lactide acid; Ref. = Reference. 


\subsection{Next Generation of Sirolimus-Eluting Resorbable Metal Scaffold (DREAMS 3rd Generation)}

The next generation of Magmaris RMS was announced, the DREAMS 3G. The major differences in this device come from the platform keeping the poly-L-Lactide Acid (PLLA) coating eluted with sirolimus. The DREAMS 3G platform is currently being tested in a variety of strut thickness $99 \mu \mathrm{m}$, $117 \mu \mathrm{m}$, and $147 \mu \mathrm{m}$ with the same strut width of $150 \mu \mathrm{m}$. The device sizes range from 2.5 to $4.0 \mathrm{~mm}$ in diameter and from 13 to $30 \mathrm{~mm}$ in length with the same resorption period of 12 months. The major difference between the previous generation is an increase in the scaffolding time to $\geq 3$ months (Table 1 ). The DREAMS 3G first-in-man and the randomized controlled trial against 2nd generation DES are planned for 2020 [43].

\section{Iron-Based Devices}

\subsection{Iron Alloy Platform Degradation}

In the benchmark corrosion test with saline immersion, a pure iron non-polymer covered platform (99.8\% of iron) with $26 \mathrm{~mm}$ in length and strut thickness of $91 \mu \mathrm{m}$ releases $41 \mathrm{mg} / \mathrm{month}$ of iron into the bloodstream, closely corresponding to the total oral intake of iron for 1 month [44]. Overtime, in the animal model analysis (rabbits), there were no observed signs of iron toxicity up to 18 months [44].

Pure iron devices are highly biocompatible and structurally sturdy, however, they present a long corrosion period and slow clearance from the vessel up to 18 months from implantation [45]. However, iron-alloy processed with nitriding technology, a thermochemical heat treatment with nitrogenation of the iron piece, adds more reliability to corrosion rate when associated with PLLA coating as seen in porcine models at 13 months $[45,46]$.

\subsection{Biocorrodible Pure Iron Devices}

The first study reported with the iron-based BRS came from NOR-I (Devon Medical, Hamburg, Germany). Based on $>99.8 \%$ of pure iron (Goodfellow, Cambridge, UK), this platform was tested in the pre-clinical environment in the descending Aorta of rabbit models [44]. Overall, 16 animals were implanted with the device and evaluated by angiography and followed by necropsy from 6,12 , or 18 months. Results showed the absence of thrombus, no significant neointima proliferation, and no toxicity (locally or systemically) [44].

Waksman et al. reported a porcine model evaluation of the Pure Iron Stent (Biotronik, Erlangen, Germany) compared to metallic stents at 28 days [47]. Overall, in the 9 pigs implanted with pure iron stents, no intra-luminal thrombus or statistically significant differences in vessel, lumen, and stent areas in the histological analysis were observed [47].

\subsection{Sirolimus-Eluting Iron Bioresorbable Coronary Scaffold (IBS)}

The major difference of this device compared to the pure iron-devices is the nitriding technology and the Zinc buffer covering the whole strut before the sirolimus-eluted PLLA coating, conferring a more reliable corrosion rate to the device and maintaining structural integrity up to 4-6 months and complete corrosion of the struts at 13 months in the pre-clinical rabbit models [45,48]. IBS (Lifetech Scientific, Shenzhen, Guangdong, China) presented a strut thickness of $70 \mu \mathrm{m}$, density of $115 \mu \mathrm{g} / \mathrm{cm}^{2}$, diameters of $2.75-3.0 \mathrm{~mm}$ and $15 \mathrm{~mm}$ in length. The IBS crossing profile was $1.04 \mathrm{~mm}$ and maximum diameter increase of $0.75 \mathrm{~mm}$ for $3.0 \mathrm{~mm}$ device. In total, 48 swines that received IBS were assessed by QCA, OCT, and histology, and their results were compared to the same number of subjects receiving Xience (Abbott Vascular, Santa Clara, CA, USA) at 7 days to 6 months follow-up. IBS results showed no significant difference in area of stenosis compared to Xience up to 6 months, while scaffold or stent thrombosis was observed during the study [45]. 


\section{Conclusions}

Almost 20 years since Tamai et al., the BRS technology concept has evolved, and current devices are aimed to overcome second-generation DES historical issues by promoting a transient scaffolding of the vessel wall, thus recovering vasomotion in the previously scaffolded segment and allowing reintervention of the target segment either by PCI or CABG if needed. This promise was partially achieved by sirolimus-eluting resorbable magnesium scaffold (Magmaris) with a relatively low TLF rate and no ST events reported in Biosolve-II and -III trials clinical outcomes report at 24 months, which was not observed in the polymeric BRS devices. In addition, a multivariate analysis comparing Magmaris and Orsiro clinical outcomes suggested similar TLF rates at 12 months, and there are no randomized studies comparing Magmaris clinical outcomes 2nd Generation DES. Lastly, in the newer generation RMS, DREAMS 3G is currently under development and its performance remains to be seen. While the iron-alloy BRS is emerging as a promising new technology, the in-man performance of these devices remains to be seen.

Author Contributions: Conceptualization, A.H.-K. and C.M.C.; writing, A.H.-K., S.W. and C.M.C.; review and editing, A.H.-K., S.W., V.B.S., M.H.R. and C.M.C.; visualization, A.H.-K., S.W., V.B.S., M.H.R. and C.M.C.; supervision, C.M.C.; project administration, C.M.C.; funding acquisition, C.M.C.

Funding: This research received no external funding.

Conflicts of Interest: The authors declare no conflict of interest.

\section{References}

1. Mauri, L.; Hsieh, W.; Massaro, J.M.; Ho, K.K.L.; D’Agostino, R.; Cutlip, D.E. Stent thrombosis in randomized clinical trials of drug-eluting stents. N. Engl. J. Med. 2007, 356, 1020-1029. [CrossRef] [PubMed]

2. Byrne, R.A.; Joner, M.; Kastrati, A. Stent thrombosis and restenosis: What have we learned and where are we going? The Andreas Grüntzig Lecture ESC 2014. Eur. Heart J. 2015, 36, 3320-3331. [CrossRef] [PubMed]

3. Witzenbichler, B.; Maehara, A.; Weisz, G.; Neumann, F.-J.; Rinaldi, M.J.; Metzger, D.C.; Henry, T.D.; Cox, D.A.; Duffy, P.L.; Brodie, B.R.; et al. Relationship between intravascular ultrasound guidance and clinical outcomes after drug-eluting stents: The assessment of dual antiplatelet therapy with drug-eluting stents (ADAPT-DES) study. Circulation 2014, 129, 463-470. [CrossRef] [PubMed]

4. Prati, F.; Kodama, T.; Romagnoli, E.; Gatto, L.; Di Vito, L.; Ramazzotti, V.; Chisari, A.; Marco, V.; Cremonesi, A.; Parodi, G.; et al. Suboptimal stent deployment is associated with subacute stent thrombosis: Optical coherence tomography insights from a multicenter matched study. From the CLI Foundation investigators: The CLITHRO study. Am. Heart J. 2015, 169, 249-256. [CrossRef] [PubMed]

5. Garg, P.; Galper, B.Z.; Cohen, D.J.; Yeh, R.W.; Mauri, L. Balancing the risks of bleeding and stent thrombosis: A decision analytic model to compare durations of dual antiplatelet therapy after drug-eluting stents. Am. Heart J. 2015, 169, 222-233. [CrossRef] [PubMed]

6. Charpentier, E.; Barna, A.; Guillevin, L.; Juliard, J.M. Fully bioresorbable drug-eluting coronary scaffolds: A review. Arch. Cardiovasc. Dis. 2015, 108, 385-397. [CrossRef] [PubMed]

7. Nishio, S.; Kosuga, K.; Igaki, K.; Okada, M.; Kyo, E.; Tsuji, T.; Takeuchi, E.; Inuzuka, Y.; Takeda, S.; Hata, T.; et al. Long-term ( $>10$ years) clinical outcomes of first-in-human biodegradable poly-l-lactic acid coronary stents: Igaki-Tamai stents. Circulation 2012, 125, 2343-2353. [CrossRef] [PubMed]

8. Heublein, B.; Rohde, R.; Kaese, V.; Niemeyer, N.; Hartung, W.; Haverich, A. Biocorrosion of magnesium alloys: A new principle in cardiovascular implant technology? Heart 2003, 89, 651-656. [CrossRef]

9. Di Mario, C.; Griffiths, H.; Goktekin, O.; Peeters, N.; Verbist, J.; Bosiers, M.; Deloose, K.; Heublein, B.; Rohde, R.; Kasese, V.; et al. Drug eluting bioabsorbable magnesium stent. J. Interv. Cardiol. 2004, 17, 391-395. [CrossRef]

10. Haude, M.; Erbel, R.; Erne, P.; Verheye, S.; Degen, H.; Böse, D.; Vermeersch, P.; Wijnbergen, I.; Weissman, N.; Prati, F.; et al. Safety and performance of the drug-eluting absorbable metal scaffold (DREAMS) in patients with de-novo coronary lesions: 12 months results of the prospective, multicentre, first-in-man BIOSOLVE-I trial. Lancet 2013, 381, 836-844. [CrossRef] 
11. Serruys, P.W.; Garcia-Garcia, H.M.; Onuma, Y. From metallic cages to transient bioresorbable scaffolds: Change in paradigm of coronary revascularization in the upcoming decade? Eur. Heart J. 2012, 33, 16b-25b. [CrossRef] [PubMed]

12. Zhang, Y.J.; Iqbal, J.; Nakatani, S.; Bourantas, C.V.; Campos, C.M.; Ishibashi, Y.; Cho, Y.K.; Veldhof, S.; Wang, J.; Onuma, Y.; et al. ABSORB Cohort B Study Investigators. Scaffold and edge vascular response following implantation of everolimus-eluting bioresorbable vascular scaffold: A 3-year serial optical coherence tomography study. JACC Cardiovasc. Interv. 2014, 7, 1361-1369. [CrossRef] [PubMed]

13. Garcia-Garcia, H.M.; Haude, M.; Kuku, K.; Hideo-Kajita, A.; Ince, H.; Abizaid, A.; Tölg, R.; Lemos, P.A.; von Birgelen, C.; Christiansen, E.H.; et al. In vivo serial invasive imaging of the second-generation drug-eluting absorbable metal scaffold (Magmaris-DREAMS 2G) in de novo coronary lesions: Insights from the BIOSOLVE-II First-In-Man Trial. Int. J. Cardiol. 2018, 255, 22-28. [CrossRef] [PubMed]

14. Hideo-Kajita, A.; Garcia-Garcia, H.M.; Haude, M.; Joner, M.; Koolen, J.; Ince, H.; Abizaid, A.; Toelg, R.; Lemos, P.A.; von Birgelen, C.; et al. First Report of Edge Vascular Response at 12 Months of Magmaris, A Second-Generation Drug-Eluting Resorbable Magnesium Scaffold, Assessed by Grayscale Intravascular Ultrasound, Virtual Histology, and Optical Coherence Tomography. A Biosolve-II Trial Sub-Study. Cardiovasc. Revasc. Med. 2019, 20, 392-398. [CrossRef] [PubMed]

15. Jahnen-Dechent, W.; Ketteler, M. Magnesium basics. Clin. Kidney J. 2012, 5 (Suppl. 1), i3-i14. [CrossRef]

16. Romani, A.M.P. Cellular Magnesium Homeostasis. Arch. Biochem. Biophys. 2011, 512, 1-23. [CrossRef]

17. Vormann, J. Magnesium: Nutrition and metabolism. Mol. Aspects Med. 2003, 24, 27-37. [CrossRef]

18. Vormann, J. Magnesium: Nutrition and Homoeostasis. AIMS Public Health 2016, 3, 329-340. [CrossRef]

19. Severino, P.; Netti, L.; Mariani, M.V.; Maraone, A.; D’Amato, A.; Scarpati, R.; Infusino, F.; Pucci, M.; Lavalle, C.; Maestrini, V.; et al. Prevention of Cardiovascular Disease: Screening for Magnesium Deficiency. Cardiol. Res. Pract. 2019, 2019, 4874921. [CrossRef]

20. Sawyer, P.N.; Srinivasan, S. The role of electrochemical surface properties in thrombosis at vascular interfaces: Cumulative experience of studies in animals and man. Bull. N. Y. Acad. Med. 1972, 48, 235-256.

21. Joner, M.; Ruppelt, P.; Zumstein, P.; Lapointe-Corriveau, C.; Leclerc, G.; Bulin, A.; Castellanos, M.I.; Wittchow, E.; Haude, M.; Waksman, R. Precinical evaluation of degradation kinetics and elemental mapping of first- and second-generation bioresorbable magnesium scaffolds. EuroIntervention 2018, 14, e1040-e1048. [CrossRef]

22. Rukshin, V.; Shah, P.K.; Cerck, B.; Finkelstein, A.; Tsang, V.; Kaul, S. Comparative antithrombotic effects of magnesium sulfate and the platelet glycoprotein $\mathrm{Ilb} / \mathrm{III}$ inhibitors tirofiban and eptifibatide in a canine model of stent thrombosis. Circulation 2002, 105, 1970-1975. [CrossRef]

23. Rukshin, V.; Azarbal, B.; Shah, P.K.; Tsang, V.T.; Shechter, M.; Finkelstein, A.; Cercek, B.; Kaul, S. Intravenous magnesium in experimental stent thrombosis in swine. Arterioscler. Thromb. Vasc. Biol. 2001, 21, 1544-1549. [CrossRef]

24. Waksman, R.; Lipinski, M.J.; Acampado, E.; Cheng, Q.; Adams, L.; Torii, S.; Gai, J.; Torguson, R.; Hellinga, D.M.; Westman, P.C.; et al. Comparison of Acute Thrombogenicity for Metallic and Polymeric Bioabsorbable Scaffolds: Magmaris Versus Absorb in a Porcine Arteriovenous Shunt Model. Circ. Cardiovasc. Interv. 2017, 10, e004762. [CrossRef]

25. Lipinski, M.J.; Acampado, E.; Cheng, Q.; Adams, L.; Torii, S.; Gai, J.; Torguson, R.; Hellinga, D.G.; Joner, M.; Harder, C.; et al. Comparison of Acute Thrombogenicity for Magnesium versus Stainless Steel Stents in a Porcine Arteriovenous Shunt Model. EuroIntervention 2018, 14, 1420-1427. [CrossRef]

26. Kemp, P.A.; Gardiner, S.M.; March, J.E.; Rubin, P.C.; Bennett, T. Assessment of the effects of endothelin-1 and magnesium sulphate on regional blood flows in conscious rats, by the coloured microsphere reference technique. Br. J. Pharmacol. 1999, 126, 621-626. [CrossRef]

27. Berthon, N.; Laurant, P.; Fellmann, D.; Berthelot, A. Effect of magnesium on mRNA expression and production of endothelin-1 in DOCA-salt hypertensive rats. J. Cardiovasc. Pharmacol. 2003, 42, 24-31. [CrossRef]

28. Basoli, A.; Cametti, C.; Satriani, F.G.; Mariani, P.; Severino, P. Hemocompatibility of stent materials: Alterations in electrical parameters of erythrocyte membranes. Vasc. Health Risk Manag. 2012, 8, 197-204. [CrossRef]

29. Song, G.L. Control of biodegradation of biocompatible magnesium alloy. Corros. Sci. 2007, 49, $1696-1701$. [CrossRef] 
30. Sillekens, W.H.; Bormann, D. Advances in Wrought Magnesium Alloys; Woodhead Publishing Series: Metals and Surface Engineering; Elsevier: Sawston, UK, 2012; pp. 427-454.

31. Chawla, S.L.; Gupta, R.K. Materials Selection for Corrosion Control; ASM International: Materials Park, $\mathrm{OH}$, USA, 1993.

32. Waksman, R.; Pakala, R.; Kuchulakanti, P.K.; Baffour, R.; Hellinga, D.; Seabron, R.; Tio, F.O.; Wittchow, E.; Hartwig, S.; Harder, C.; et al. Safety and efficacy of bioabsorbable magnesium alloy stents in porcine coronary arteries. Catheter. Cardiovasc. Interv. 2006, 68, 607-617; discussion 618-619. [CrossRef]

33. Böse, D.; Eggebrecht, H.; Haude, M.; Schmermund, A.; Erbel, R. First absorbable metal stent implantation in human coronary arteries. Am. Heart Hosp. J. 2006, 4, 128-130. [CrossRef]

34. Ozaki, Y.; Garcia-Garcia, H.M.; Hideo-Kajita, A.; Kuku, K.O.; Haude, M.; Ince, H.; Abizaid, A.; Tölg, R.; Lemos, P.A.; von Birgelen, C.; et al. Impact of procedural characteristics on coronary vessel wall healing following implantation of second-generation drug-eluting absorbable metal scaffold in patients with de novo coronary artery lesions: An optical coherence tomography analysis. Eur. Heart J. Cardiovasc. Imaging 2018, 20, 916-924. [CrossRef]

35. Campos, C.M.; Muramatsu, T.; Iqbal, J.; Zhang, Y.J.; Onuma, Y.; Garcia-Garcia, H.M.; Haude, M.; Lemos, P.A.; Warnack, B.; Serruys, P.W. Bioresorbable drug-eluting magnesium-alloy scaffold for treatment of coronary artery disease. Int. J. Mol. Sci. 2013, 14, 24492-24500. [CrossRef]

36. Erbel, R.; Di Mario, C.; Bartunek, J.; Bonnier, J.; de Bruyne, B.; Eberli, F.R.; Erne, P.; Haude, M.; Heublein, B.; Horrigan, M.; et al. Temporary scaffolding of coronary arteries with bioabsorbable magnesium stents: A prospective, non-randomised multicentre trial. Lancet 2007, 369, 1869-1875. [CrossRef]

37. Wittchow, E.; Adden, N.; Riedmüller, J.; Savard, C.; Waksman, R.; Braune, M. Bioresorbable drug-eluting magnesium-alloy scaffold: Design and feasibility in a porcine coronary model. EuroIntervention 2013, 8, 1441-1450. [CrossRef]

38. Haude, M.; Ince, H.; Abizaid, A.; Toelg, R.; Lemos, P.A.; von Birgelen, C.; Christiansen, E.H.; Wijns, W.; Neumann, F.J.; Kaiser, C.; et al. Safety and performance of the second-generation drug-eluting absorbable metal scaffold in patients with de-novo coronary artery lesions (BIOSOLVE-II): 6 month results of a prospective, multicentre, non-randomised, first-in-man trial. Lancet 2016, 387, 31-39. [CrossRef]

39. Haude, M.; Ince, H.; Abizaid, A.; Toelg, R.; Lemos, P.A.; von Birgelen, C.; Christiansen, E.H.; Wijns, W.; Neumann, F.J.; Kaiser, C.; et al. Sustained safety and performance of the second-generation drug-eluting absorbable metal scaffold in patients with de novo coronary lesions: 12-month clinical results and angiographic findings of the BIOSOLVE-II first-in-man trial. Eur. Heart J. 2016, 37, 2701-2709. [CrossRef]

40. Haude, M.; Ince, H.; Kische, S.; Abizaid, A.; Tölg, R.; Alves Lemos, P.; Van Mieghem, N.M.; Verheye, S.; von Birgelen, C.; Christiansen, E.H.; et al. Sustained safety and clinical performance of a drug-eluting absorbable metal scaffold up to 24 months: Pooled outcomes of BIOSOLVE-II and BIOSOLVE-III. EuroIntervention 2017, 13, 432-439. [CrossRef]

41. Hideo-Kajita, A.; Garcia, H.G.; Azizi, V.; Ince, H.; Kische, S.; Abizaid, A.; Töelg, R.; Lemos, P.; Van Mieghem, N.; Verheye, S.; et al. Comparison of Clinical Outcomes Between Magmaris (DREAMS 2G) and Orsiro Drug-Eluting Stents: Pooled Patient Level Analysis from BIOSOLVE II-III and BIOFLOW II trials. J. Am. Coll. Cardiol. 2018, 71, A1109. [CrossRef]

42. Hideo-Kajita, A.; Garcia-Garcia, H.; Azizi, V.; Ince, H.; Kische, S.; Abizaid, A.; Töelg, R.; Lemos, P.A.; Van Mieghem, N.M.; Verheye, S.; et al. CRT-600.07 Comparison of Clinical Outcomes Between Magmaris (dreams 2g) and Orsiro Drug Eluting Stents: Pooled Patient Level Analysis from Biosolve II-III and Bioflow II Trials. JACC Cardiovasc. Interv. 2018, 11, S43. [CrossRef]

43. Haude, M. Future developments: Next gen Magmaris. In Proceedings of the EuroPCR, Paris, France, 21 May 2019.

44. Peuster, M. A novel approach to temporary stenting: Degradable cardiovascular stents produced from corrodible metal-Results 6-18 months after implantation into New Zealand white rabbits. Heart 2001, 86, 563-569. [CrossRef]

45. Zheng, J.-F.; Qiu, H.; Tian, Y.; Hu, X.-Y.; Luo, T.; Wu, C.; Tian, Y.; Tang, Y.; Song, L.F.; Li, L.; et al. Preclinical Evaluation of a Novel Sirolimus-Eluting Iron Bioresorbable Coronary Scaffold in Porcine Coronary Artery at 6 Months. JACC Cardiovasc. Interv. 2019, 12, 245-255. [CrossRef] 
46. Lin, W.-J.; Zhang, D.-Y.; Zhang, G.; Sun, H.-T.; Qi, H.-P.; Chen, L.-P.; Liu, Z.; Gao, R.; Zheng, W. Design and characterization of a novel biocorrodible iron-based drug-eluting coronary scaffold. Mater. Des. 2016, 91, 72-79. [CrossRef]

47. Waksman, R.; Pakala, R.; Baffour, R.; Seabron, R.; Hellinga, D.; Tio, F.O. Short-Term Effects of Biocorrodible Iron Stents in Porcine Coronary Arteries. J. Interv. Cardiol. 2008, 21, 15-20. [CrossRef]

48. Lin, W.; Qin, L.; Qi, H.; Zhang, D.; Zhang, G.; Gao, R.; Qiu, H.; Xia, Y.; Cao, P.; Wang, X.; et al. Long-term in vivo corrosion behavior, biocompatibility and bioresorption mechanism of a bioresorbable nitrided iron scaffold. Acta Biomater. 2017, 54, 454-468. [CrossRef]

(C) 2019 by the authors. Licensee MDPI, Basel, Switzerland. This article is an open access article distributed under the terms and conditions of the Creative Commons Attribution (CC BY) license (http://creativecommons.org/licenses/by/4.0/). 